\title{
Effect of Packaging on the Stability of Stored Dry Silver Cyprinid (Rastrineobola argentea)
}

\author{
Mary Namwanje (Corresponding author) \\ Department of Food Technology and Nutrition, Makerere University \\ P. O. Box 7062, Kampala, Uganda
}

Tel: 256-700-805-707Ｅ-mail: marynk20@gmail.com

\begin{abstract}
Julia Kigozi
Department of Agricultural \& Bio-systems Engineering, Makerere University Tel: 256-772-609 649 E-mail: jbulyakigozi@yahoo.com
\end{abstract}

Ivan M. Mukisa

Department of Food Technology and Nutrition, Makerere University

Email: ivanmukisa@gmail.com

Isaac Omagor

Department of Food Technology and Nutrition, Makerere University

E-mail: omagor.isaac8@gmail.com

\author{
Sloans K. Chimatiro \\ WorldFish, Lusaka, Zambia \\ E-mail: S.Chimatiro@cgiar.org
}

Received: December 20, 2020 Accepted: August 10, 2021 Published: November 9, 2021

doi:10.5296/jfs.v10i1.18642ＵRL: https://doi.org/10.5296/jfs.v10i1.18642 


\title{
M Macrothink
}

\begin{abstract}
Dried silver cyprinid (Rastrineobola argentea) has the potential to provide an affordable and accessible food-based strategy to fight malnutrition among Ugandans and enrich diets of the vulnerable persons. However, there is inadequate information on changes in the nutritional content and safety of stored dry silver cyprinid along the local handling chain. This study evaluated the effect of conventionally used packaging on microbial safety and nutrient quality of dry silver cyprinid during storage. Freshly dried silver cyprinid was obtained from stores at four landing sites on Lake Victoria and stored in open and closed gunny bags for 8 weeks. Samples were collected at 0, 1, 2, 4, 6 and 8 weeks of storage and assessed for nutritional and microbial quality. The type of packaging used (open or closed gunny bags) had no significant effect on most nutrient content and microbial safety parameters $(p>0.05)$ except iron content, aflatoxin content, and TVBN content. Open gunny bags had higher aflatoxin content, greater iron degradation and greater variation in TVBN as compared to closed gunny bags throughout the storage duration. The observed difference in some of the quality parameters can be attributed to increased permeability to oxygen and moisture in open gunny bags as compared to closed gunny bags.
\end{abstract}

Keywords: Silver cyprinid, Rastrineobola argentea, Packaging, Nutritional quality, Microbial safety, Aflatoxins

\section{Introduction}

The fisheries industry provides high quality proteins, micro nutrients and ultimately employment, thus contributing to food security of various individuals and economic development worldwide. Silver cyprinid (Rastrineobola argentea) is a small pelagic fish of growing importance in Uganda because of its economic and nutrition contribution. Dry silver cyprinid contains substantial amounts of high-quality proteins, calcium, iron and vitamin A (Kabahenda et al., 2011). Therefore, utilizing silver cyprinid can enrich diets of vulnerable individuals.

Silver cyprinid is a cheap fish that can be incorporated in complementary diets of infants if they are to meet the specified nutrient requirements. However, dry silver cyprinid could be prone to changes in nutrient content, taste and flavor during storage (Kabahenda et al., 2011; Ibengwe, 2011). In addition, exposure to microbes (Immaculate et al., 2013), lipid oxidation agents and insects (Kabahenda et al., 2009) through poor post-harvest handling practices (Ssebisubi, 2013) and poor packaging augment quality deterioration. Therefore, all these compromise the nutritional quality of silver cyprinid.

In Uganda, dried silver cyprinid is packaged in polythene bags (URN, 2012), which can be closed or open gunny bags or is just left in the open (Kabahenda et al., 2009; Ssebisubi, 2011, Masette, 2013) at ambient temperature of about 25-30 ${ }^{\circ} \mathrm{C}$ (Farzana et al., 2014). The reasons for utilization of these package options range from their ability to maintain quality (Wasswa R., personal communication, Dec 10, 2016), to the lack of motivation to modify these packaging practices and the market availability or demand (Legros \& Luomba, 2011). Nonetheless, all these packaging options are permeable to oxygen and moisture and thus allow the dry fish to exchange moisture and air with the environment (Alcock et al., 2007).

Moreover, open storage at ambient temperature encourages contamination by mycotoxin 


\section{Macrothink Institute ${ }^{T M}$}

producing fungi (Sam et al., 2015); insect infestation, which affects sensory properties and leads to nutrient degradation, hence post-harvest fish losses (Getu et al., 2015, Atanda et al., 2013). The resultant nutrient degradation and microbial safety of stored dry silver cyprinid could lead to limited nutrient availability and utilization of fish by humans especially the vulnerable groups. Therefore, this study evaluated the effect of the commonly use packaging options (open and closed gunny bags) on the nutrient and microbial quality of dried silver cyprinid. Packaging options that minimize quality losses can be optimized and promoted for general storage and handling of silver cyprinid.

\section{Materials and Methods}

Samples were picked from different Lake Victoria landing sites and the storage studies were carried out in Kampala, Uganda.

\subsection{Study Design and Sampling}

About 24 kilograms of dry silver cyprinid were obtained from a selected store from each of the four landing sites. These samples were pooled together to get a representative sample which was later repacked. The dried fish was repackaged in $2 \mathrm{~kg}$ open and closed gunny bags and stored at ambient temperature in Kampala (Figure 1).

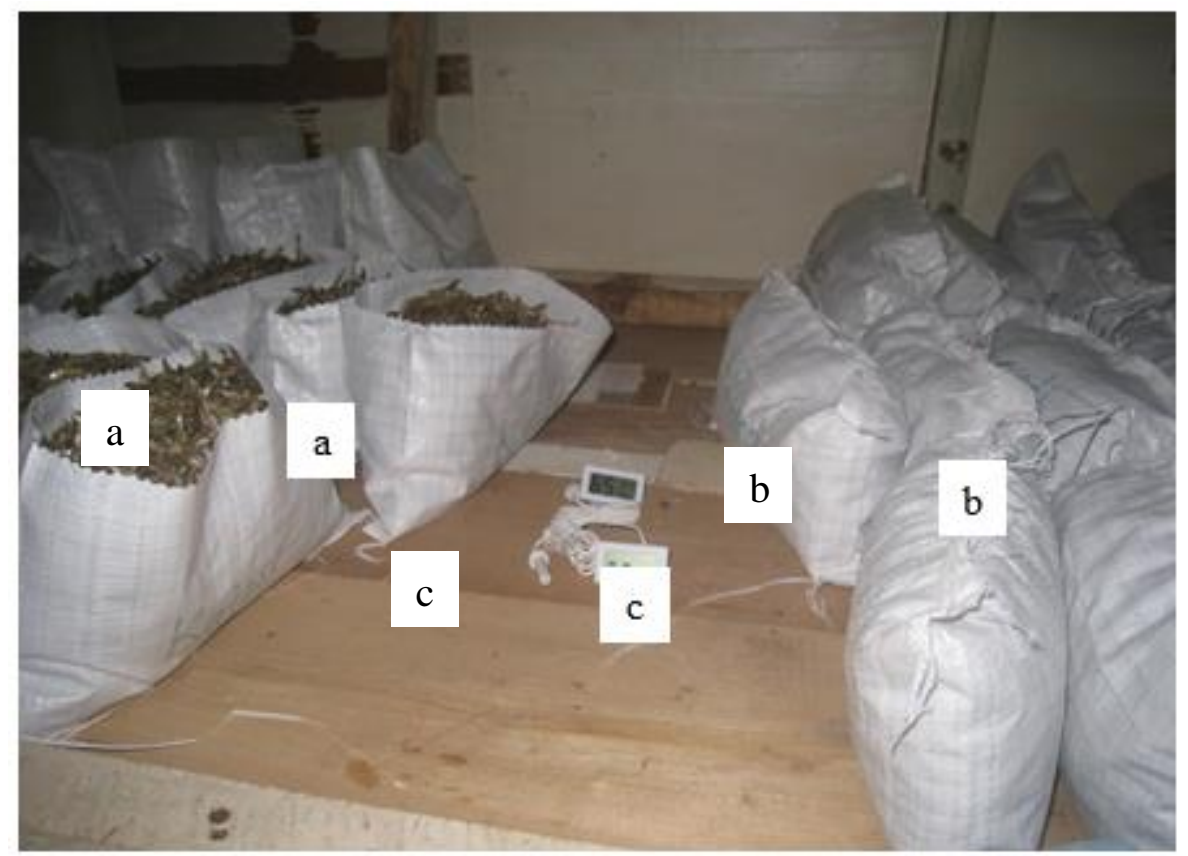

Figure 1. Simulation storage experiment of dry silver cyprinid: a-silver cyprinid placed in open gunny bags, b-silver cyprinid placed in closed gunny bags, c- probes used to record temperature and relative humidity of the store). Photo credit by Mary Namwanje, 2017

Sampling for quality analyses was done before storage (time, $\mathrm{t}=0$ ), after 1, 2, 4, 6 and 8 weeks in storage. The analyses were carried out in triplicate. 


\section{1) Macrothink}

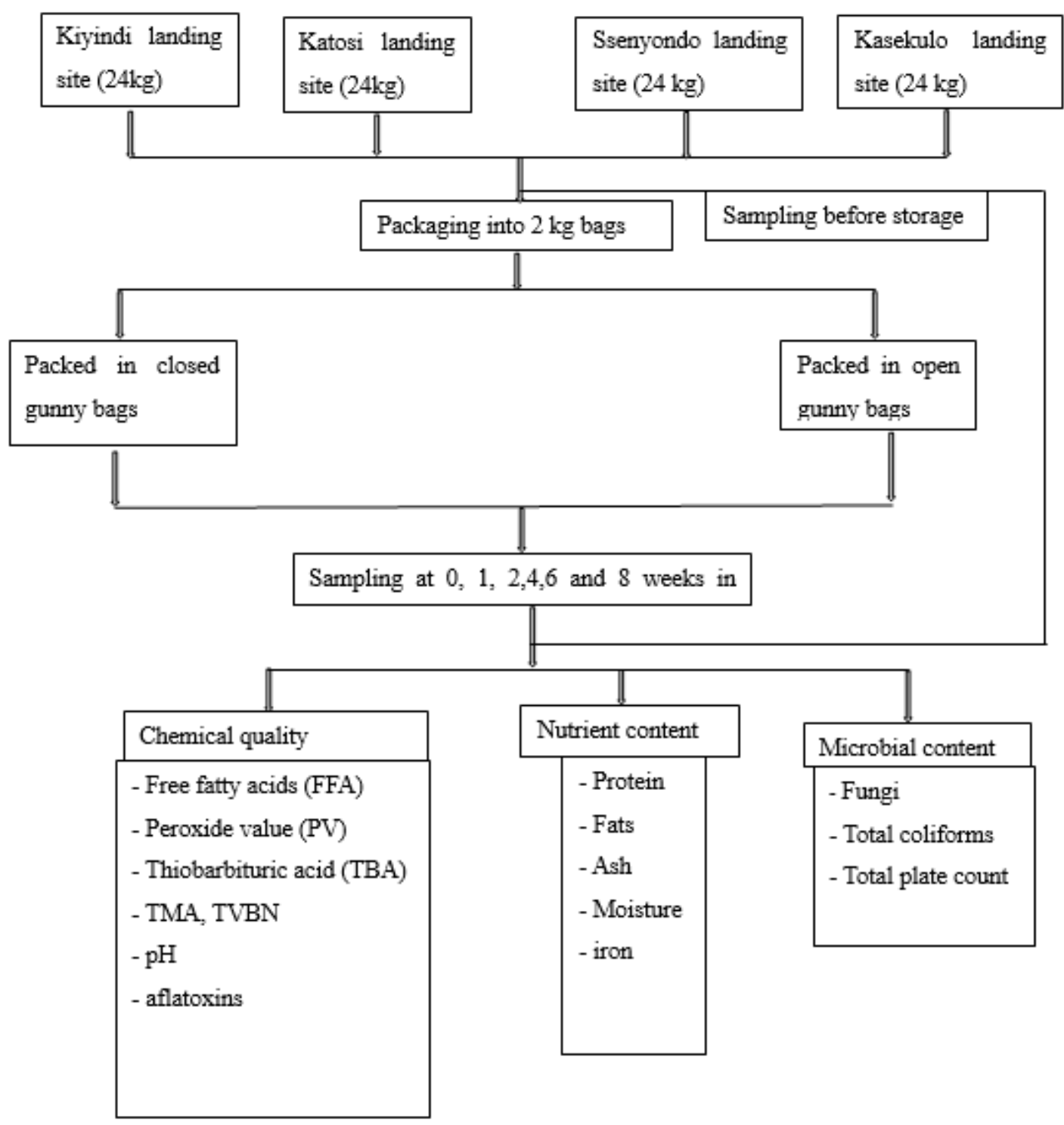

Figure 2. Study design and analyses carried out during the two-months' storage experiment that simulated the packaging and storage conditions at landing site stores for dry silver cyprinid

\subsection{Analyses}

Laboratory analyses included proximate composition, lipid oxidation products, $\mathrm{pH}$, total coliform, total plate count, yeast \& moulds, and microbial degradation products. Moisture content of samples was determined following the oven method procedure (AOAC, 1996). Crude protein was quantified using the Kjeldahl method (Kirk \& Sawyer, 1991) and a conversion factor of 6.25 (ISO 5983-2, 2009). Crude fat was determined using the Soxhlet extraction method (AOAC, 1996) while ash content was determined using the dry ashing method (AOAC, 2005). Iron content was determined according to Atomic absorption spectrophotometry (Perkin Elmer, 400 manual).

Degree of lipid oxidation was determined using acid value test, thiobarbituric acid test and peroxide value (Angelo, 1996; Mbunda, 2012; Neilsen, 2010). To measure pH, about $5 \mathrm{~g}$ of 


\section{Macrothink}

powdered dry fish sample was dissolved in $75 \mathrm{~mL}$ of water in a beaker and a standardized $\mathrm{pH}$ meter (HI 2210) used to record the $\mathrm{pH}$ of the solution (AOAC, 1995). TVBN and TMA were measured using the protocol by Malle and Poumeyrol, (1989). Aflatoxin content was determined according to the method of Romer Labs (2014) with slight modifications. Microbes (Yeasts \& moulds, total coliforms and total plate count) were quantified after culturing on growth media.

Throughout the entire study, temperature and humidity of the experiment store was recorded thrice per day (8:00 am, 12:00 noon and 6:00 pm) for 2 months using digital probes (Figure 1c).

\subsection{Statistical Analyses}

One-way ANOVA was used to test for differences in analyzed parameters of dry silver cyprinid at varied weeks in the store. Regressions and correlations were run between different variables inorder to explain whether there was any relationship among observed variables. Statistical analysis of data was carried out using SPSS software (version 21) and significant differences were observed at $\mathrm{p}<0.05$.

\section{Results}

\subsection{Effect of Packaging on Nutrient Content}

Table 1 and Figure 3 summarize the effect of packaging on nutrient retention in stored silver cyprinid. Although storage duration affected nutrient retention, the type of packaging used (open or closed gunny bags) had no significant effect on retention of nutrients ( $p>0.05$; Figure 3). Protein content of dried silver cyprinid increased from $49 \%$ to $53.52 \%$. Fat content decreased from $9.38 \%$ to $8.56 \%$. Moisture content decreased from $14.09 \%$ to $12.40 \%$ (Figure 3 ). Ash content increased from $13.62 \%$ to $14.23 \%$.

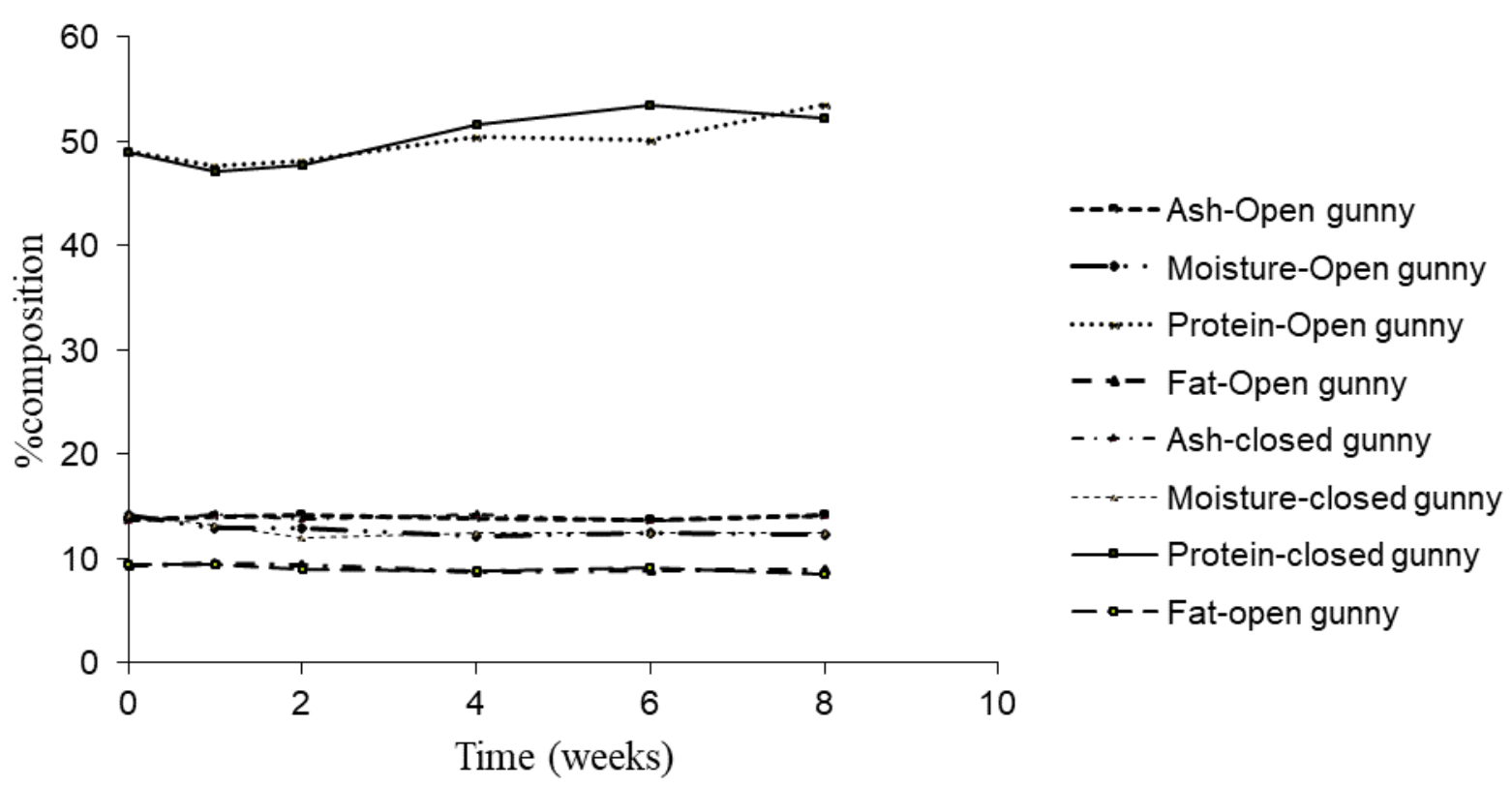

Figure 3. Nutrient content (\%) of dry silver cyprinid stored up to 8 weeks in open and closed gunny bags. 


\section{Macrothink}

The type of packaging used (open or closed gunny bags) had a significant effect on retention of iron $(\mathrm{p}<0.05$; Table 1$)$. Storing silver cyprinid in open gunny bags led to a significant reduction in iron content $(\mathrm{p}<0.05)$.

Table 1. Iron content of dried silver cyprinid stored in open and closed gunny bags

\begin{tabular}{lll}
\hline Storage time & Package & Iron content $(\mathrm{mg} / 100 \mathrm{~g})$ \\
\hline 0 weeks & None (Control) & $15.3 \pm 0.4^{\mathrm{a}}$ \\
8 weeks & Open gunny & $12.5 \pm 1.1^{\mathrm{b}}$ \\
& Closed gunny & $15.2 \pm 2.3^{\mathrm{a}}$ \\
\hline
\end{tabular}

Different superscipts $(a, b)$ along the columns for the iron content show significant differences $(p<0.05)$ in the variable between the packages.

\subsection{Effect of Packaging on Microbial Quality of Silver Cyprinid}

Although storage duration affected the microbial quality of silver cyprinid, the type of packaging (open or closed gunny bags) had no significant effect on microbial quality of the fish ( $(p>0.05$; Figure 4). Total plate counts, total coliforms and fungal counts decreased from 7.1 to $6.6 \log \mathrm{cfug}^{-1}, 4.2$ to $2.3 \mathrm{log}_{\mathrm{cfug}}{ }^{-1}, 3.9$ to $2.3 \mathrm{log} \mathrm{cfug}^{-1}$ respectively during the eight weeks of storage (Figure 4).

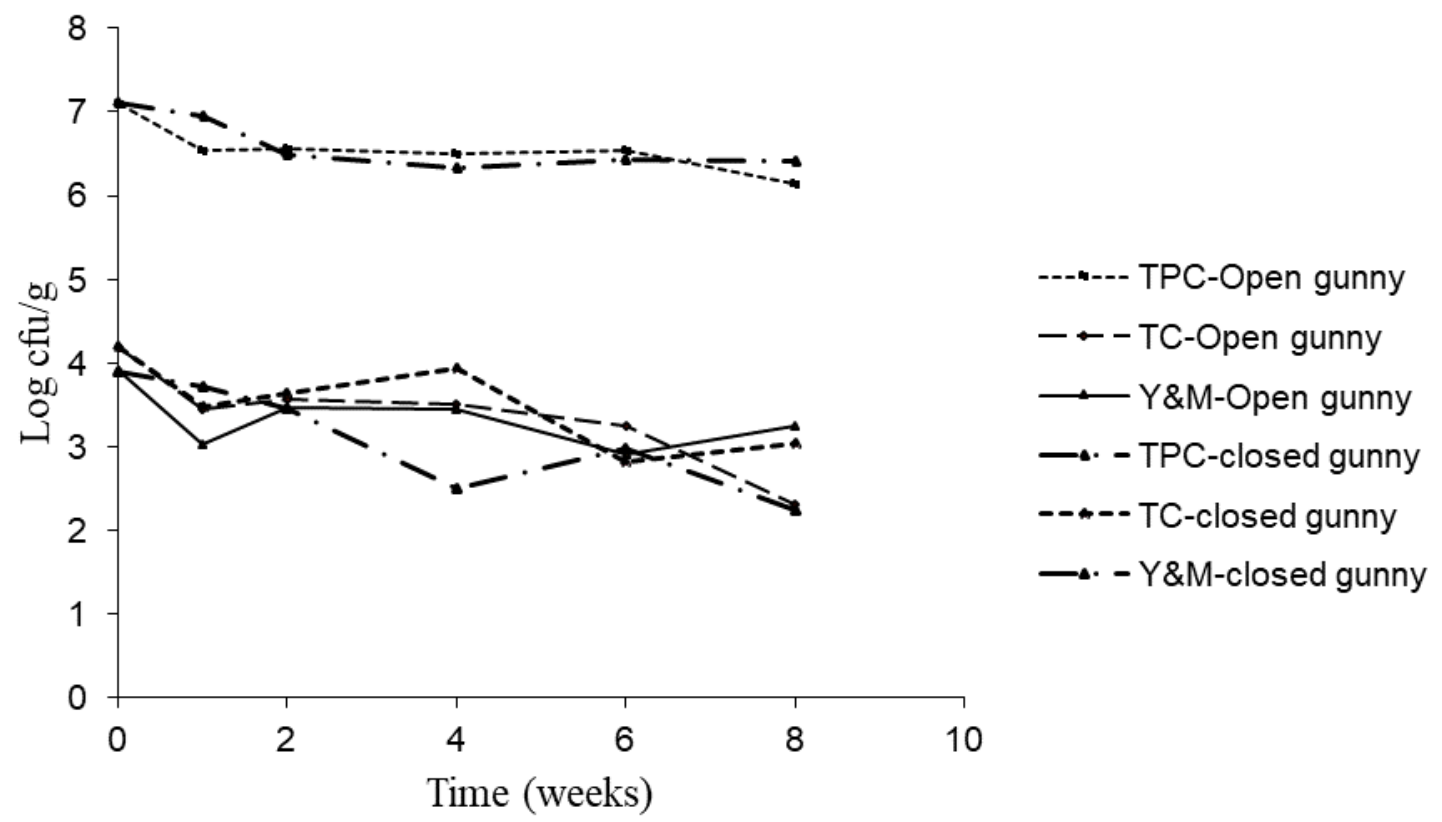

Figure 4. Changes in the content of different microbes on dried silver cyprinid during the 8 weeks of storage 


\section{Al Macrothink}

\subsection{Effect of Packaging on the Chemical Quality of Silver Cyprinid}

The chemical quality was evaluated using lipid breakdown indicators (peroxide value, TBARs and free fatty acid content), protein degradation products (TMA and TVBN) and aflatoxin content. The type of packaging used (open or closed gunny bags) did not have a significant effect on peroxide value, TBARs, free fatty acid content, and TMA ( $p>0.05)$. However, the packaging type significantly affected aflatoxins and TVBN content of silver cyprinid (Table 2 and Figure 6). Silver cyprinid stored in open gunny bags had significantly higher TVBN and aflatoxin $(\mathrm{p}<0.05)$ content than that in closed gunny bags. Throughout the 8 weeks of storage, TVBN decreased from 6.3 to $3.24 \mathrm{mgN} / 100 \mathrm{~g}$.

Table 2. Aflatoxin content of dried silver cyprinid stored in open and closed gunny bags

\begin{tabular}{lll}
\hline Storage time & Package & Aflatoxin content $(\mathrm{ppb})$ \\
\hline 0 weeks & None (control) & $12.4 \pm 1.3^{\mathrm{a}}$ \\
8 weeks & Open gunny & $14.7 \pm 0.6^{\mathrm{b}}$ \\
& Closed gunny & $13.3 \pm 1.4^{\mathrm{a}}$ \\
\hline
\end{tabular}

Different superscipts $(a, b)$ along the aflatoxin content columns show significant differences $(p<0.05)$ in the variable between the packages used.

In general, free fatty acid (FFA)content increased from $0.0597 \mathrm{mg} \mathrm{KOHg}^{-1}$ to $0.0697 \mathrm{mg}$ $\mathrm{KOHg}^{-1}$ (Figure 5). Peroxide value, TBARs content, $\mathrm{pH}$, TMA content, and TVBN content decreased from $1.94 \mathrm{meqO}_{2} / \mathrm{kg}$ to undetectable levels, 71.38 to $48.43,6.43$ to 6.26 (Figure 5), 3.26 to $1.89 \mathrm{mgN} / 100 \mathrm{~g}$, and $6.3 \mathrm{mgN} / 100 \mathrm{~g}$ to $3.24 \mathrm{mgN} / 100 \mathrm{~g}$ (Figure 6), respectively during the eight weeks of storage. During the first 4 weeks in storage, FFA (Figure 5 A) and TVBN increased (Figure 6A) before decreasing but TMA increased in the first 2 wks then decreased (Figure 6 B). 

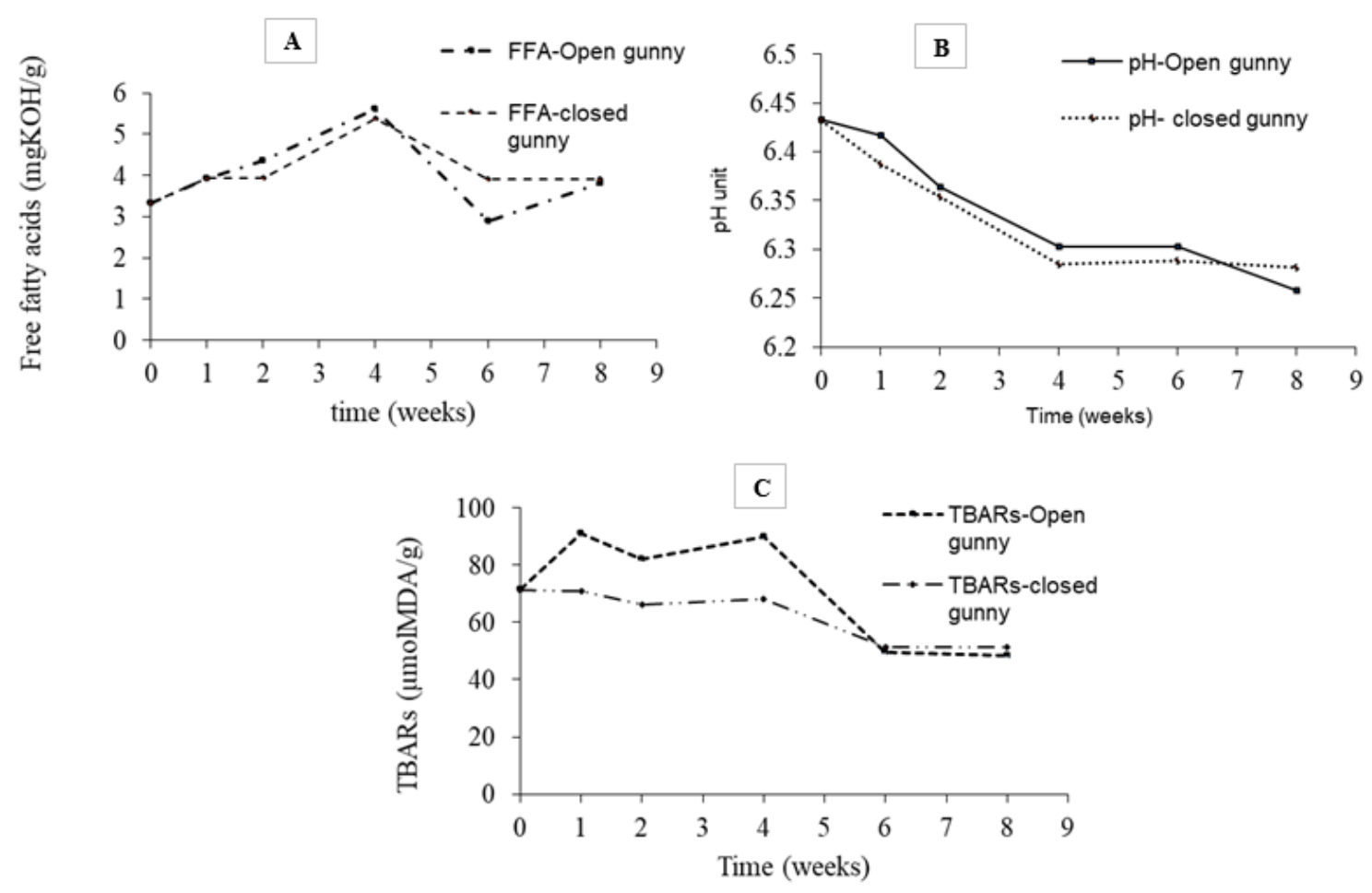

Figure 5. $\mathrm{FFA}(\mathrm{A}), \mathrm{TBARs}(\mathrm{C})$ and $\mathrm{pH}(\mathrm{B})$ of stored dried silver cyprinid
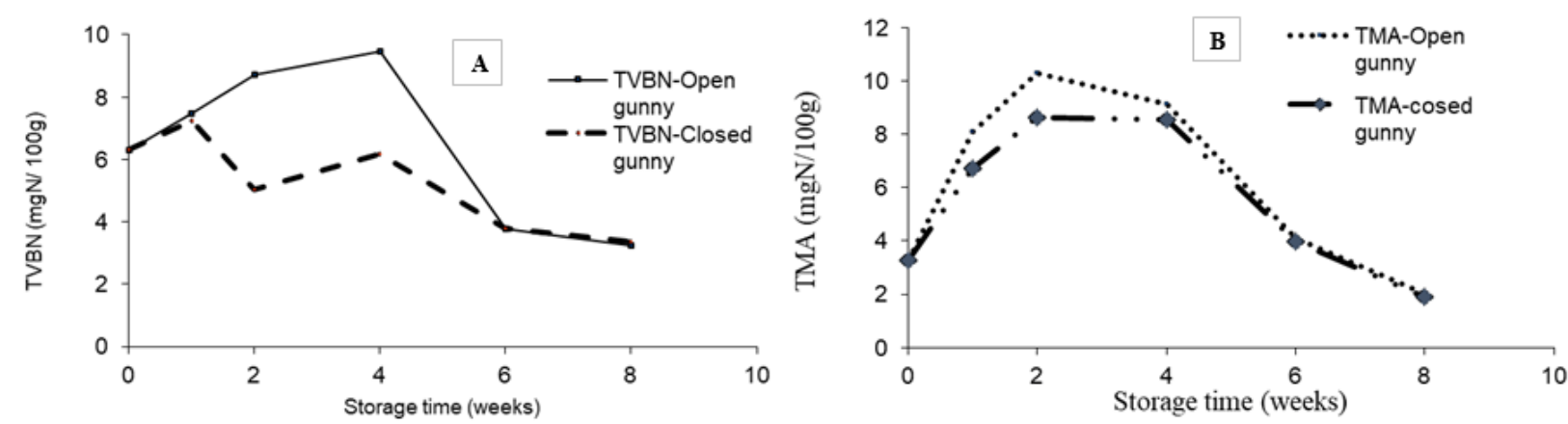

Figure 6. TVBN(A) and TMA(B) content of stored dried silver cyprinid

\section{Discussion}

\subsection{The Effect of Packaging on Nutrient Content of Stored Silver Cyprinid}

The packaging (open and closed gunny) did not significantly affect the nutritional composition (moisture, ash protein and fat content) of the stored dry silver cyprinid over the 8 weeks' storage duration, despite the observed increase in protein content which could be due to reduction in moisture with storage Nonetheless, it is likely that the difference in permeability of the closed gunny and open gunny bags was not sufficient to facilitate changes in nutritional composition.

The type of packaging used (open or closed gunny bags) had a significant effect on retention 
of iron content in dry silver cyprinid. The difference in iron content between open and closed gunny bag stored fish could be attributed to the varied rates of lipid oxidation (Sam et al., 2015 ) coupled with long storage duration at ambient temperature. Since open gunny bags are more permeable to oxygen and moisture as compared to closed gunny bags, these may have facilitated a faster rate of lipid oxidation (Alcock et al., 2007).

\subsection{The Effect of Packaging on Microbial Content of Stored Dry Silver Cyprinid}

The packaging (open and closed gunny) did not significantly affect the microbial quality of the stored dry silver cyprinid over the 8 weeks of storage duration and it was similarly reported by Ayodele and Oyeleye, (2013). This can be attributed to some of the properties of gunny bags such as their permeability to oxygen and moisture which allow contents to breathe (Alcock et al., 2007). Thus, the rate of oxygen and moisture exchange between the two different packages (open and closed gunny) and the environment created conditions that would facilitate microbial growths at almost the same rate (Kilic, 2009; Vazirianzadeh, 2008, Glucas, 1982).

The presence of microbes in fish results in economic losses, detrimental effects to human health and non-palatability of the fish product thus giving a negative correlation between TPC and over all acceptability (Reza et al., 2015).

\subsection{The Effect of Packaging on Chemical Quality of Stored Dry Silver Cyprinid}

The packaging (open and closed gunny) did not significantly affect most of the chemical quality parameters of stored dry silver cyprinid over the 8 weeks of storage except TVBN and aflatoxins concentration. The lack of significant difference can be attributed to properties of gunny bags such as their permeability to oxygen and moisture which allow contents to breathe, support microbial and enzyme activity (Alcock et al., 2007, Immaculate et al., 2013; Saritha et al., 2012). This is in disagreement with Odoli (2015) and Nguyen et al., (2012) who reported packing method to influence lipid oxidation during storage.

The consequences of significant difference in chemical quality of stored dry silver cyprinid include deterioration of flavour, appearance, odour, colour and palatability of the fish. Interaction of oxidation products with proteins would lower the availability of essential amino acids and thus a negative correlation between protein content and lipid content (Diniz et al., 2013).

The FFA content was below acceptable limit of $3 \mathrm{mgKOH} / \mathrm{g}$ and thus if FFA content was the only quality assessment carried out the stored dry fish would be of good quality. Although the $\mathrm{pH}$ of stored silver cyprinid reduced with increased storage time, it remained within the range of 6.0-6.9 for good quality (Kakati et al., 2017). During fish spoilage, a $\mathrm{pH}$ above 7.0 indicates poor quality, $\mathrm{pH}$ increases with increasing storage time was reported in sun dried and salted Shoal fish at room temperature (Farid et al., 2014). Decrease in $\mathrm{pH}$ of this study can be attributed to decrease in moisture content to a point that can still favor microbial growth (Onyuka et al., 2014, Gandotra et al., 2012). The reduction in TMA content of dried silver cyprinid was probably due to conversion of TMA to yield other bases such as ammonia, dimethyl amine and trimethylamine.

The significant effect of packaging (open or closed gunny bags) on the aflatoxin content would be attributed to the varied permeability of open and closed gunny bags and exposure to 


\section{Mll Macrothink}

moisture and air (Sam et al., 2015). Open gunny bags which are more permeable to oxygen and moisture could have provided ideal environment for the aflatoxin producing mold compared to closed gunny bags. However, on the overall stored silver cyprinid samples contained aflatoxin levels higher than the recommended level for baby foods as well as for the adults (10 ppb: EAS., 2014).

Generally, peroxide value, total volatile basic nitrogen and tri methyl amine were within the acceptable limits of $5 \mathrm{meqO}_{2} / \mathrm{kg}, 35 \mathrm{mgN} / 100 \mathrm{~g}, 15 \mathrm{mgN} / 100 \mathrm{~g}$ (Codex 2017, Connell, 1995, Gopakumar, 2002; Karim et al., 2011) respectively, and this suggested that the fish was not spoilt and could therefore be having a shelf life of at least two months in closed or open gunny bags at ambient temperature of storage.

\section{Conclusions}

Packaging affected microbial quality, physical chemical properties and protein content of the stored samples. Storing dried silver cyprinid in closed gunny bag slows down the rate of protein and lipid degradation by microbes, oxidation/hydrolysis of fish. Therefore, dried fish kept in closed gunny bags may keep longer than that in open gunny bags. The study has also shown that dried silver cyprinid can remain stable or at least two months when stored in open or closed gunny bags at ambient temperature. Future studies should evaluate the potential of using hermetic storage to enhance the shelf life stability of dried silver cyprinid. Further packaging options that minimize quality losses can be optimized and promoted for general storage and handling of silver cyprinid.

\section{Conflict of interest statement}

The authors declare that they have no conflict of interest.

\section{Acknowledgement}

The authors thank the European Union under Fish Trade Project through World Fish Center, AU-IBAR and NEPAD Planning and Coordination Agency (NPCA) for funding this research. The authors acknowledge the assistance of Semwanga Nathan Makerere University for guidance on data analysis and scientific writing.

\section{References}

Alcock, B., Cabrera, O. N., Barkoula, M. N., Spoelstra, B. A., Loos, J., \& Peijs, T. (2007). The mechanical properties of woven tape all polypropylene composites. Composites: Part A, 38, 147-161. https://doi.org/10.1016/j.compositesa.2006.01.003

Angelo, A. J. (1996). Lipid Oxidation In Foods. Critical Reviews in Food Science and Nutrition, 36(3), 175-224. https://doi.org/10.1080/10408399609527723

AOAC. (1996). Association of Official Analytical Chemists. Official Methods of Analysis, 16th ed. Gaithersburg, Maryland.

AOAC. (2005). Official Methods of Analysis (18 ed.). AOAC International Gaithersburg, MD.

Atanda, O., Makun, H. A., Ogara, I. M., Edema, M., Idahor, K. O., Margaret, E., ... Oluwabamiwo. (2013). Fungal and Mycotoxin Contamination of Nigerian Foods and Feeds. https://doi.org/10.5772/55664 


\section{Macrothink}

Ayodele, O. O., \& Oyeleye, J. O. (2013). Microbial Load (Bacteria, Coliform and Mould Count/Flora) of Some Common Hot Smoked Freshwater Fish Species Using Different Packaging Materials. Food and Nutrition Sciences, 4, 1201-1208. https://doi.org/10.4236/fns. 2013.412154

Connell, J. J. (1995). Control of Fish Quality. 4th Edn., Farnham Surrey. Fishing News Books Ltd., WileyBlackwell.

Diniz, G. S., Barbarino E., Oiano-Neto, J., Pacheco, S., \& Lourenço1, S. O. (2013). Gross chemical profile and calculation of nitrogen-to-protein conversion factors for nine species of fishes from coastal waters of Brazil. Lat. Am. J. Aquat. Res., 41(2), 254-264. https://doi.org/10.3856/vol41-issue2-fulltext-5

East African Standard. (2014). Dried fish Rastrineobolaargentea-Specification DEAS 826:2014. ICS 67.120.30.

Farid, F. B., Latifa, G. A., Nahid, M. N., \& Begum, M. (2014). Comparison of the changes in Phisico-chemical Characteristics of Dry Salted Snake-head Shoal (Channa striatus Bloch, 1801) and Taki (Channa punctatus Bloch, 1793) at Room temperature (270-310C). Res. J. Animal, Veterinary and Fishery Sci, 2(9), 18-23.

Farzana, B. F., Gulshan, A. L., Mosarrat, N. N., \& Mohajira, B. (2014). Effect of Sun-drying on proximate composition and $\mathrm{pH}$ of Shoal fish (C. striatus; Bloch, 1801) treated with Salt and Salt-turmeric storage at Room Temperature (270 - 300C). IOSR Journal of Agriculture and Veterinary Science (IOSR-JAVS).

Frankel, E. N. (1980). Lipid oxidation - a review. Progress in Lipid Research, 19, 2-18. Pergamon Press Ltd 1980. Printed in Great Britain. https://doi.org/10.1016/ 0163-7827(80)90006-5

Fraser, O., \& Sumar, S. (1998). Compositional changes and spoilage in fish. Nutr. Food Sci., 5, 275-279. https://doi.org/10.1108/00346659810224208

Gandotra, R, Meenakshi, K., Sweta, G., \& Shallini, S. (2012). Change In Proximate Composition And Microbial Count By Low Temperaturepreservation In Fish Muscle Of Labeo Rohita (HamBuch) IOSR J. Pharm. Biol. Sci, 2(1), 13-17. https://doi.org/10.9790/3008 $-0211317$

Getu, A., Misganaw, K., \& Bazezew, M. (2015). Post-harvesting and Major Related Problems of Fish Production. Fish Aquac J, 6, 154. https://doi.org/10.4172/2150-3508.1000154

Glucas, I. J. (1982). Present fish drying techniques in Zambia and suggested improvements. A report prepared for fisheries development project. Rome.

Gopakumar, K. (2002). Textbook of fish processing technology, Indian council of agricultural research New Delhi.

Ibengwe, L. (2011). Reducing Post-harvest Losses of the Artisanal Dagaa (Rastrineobola argentea) Fishery In Lake Victoria, Tanzania: a Cost and Benefit Analysis

Immaculate, K., Sinduja, P., Velammal, A., \& Patterson, J. (2013). International Food Research Journal, 20(4), 1855-1859.

Kabahenda, M. K., Amega, R., Okalany, E., Husken, S. M. C., \& Heck, S. (2011). Protein and Micronutrient Composition of Low-Value Fish Products Commonly Marketed in the 


\section{MInstitute ${ }^{\text {Mink }}$}

Lake Victoria Region. World Journal of Agricultural Sciences, 7 (5), 521-526.

Kabahenda, M. K., Omony, P., \& Hüsken, S. M. C. (2009). Post-harvest handling of low-value fish products and threats to nutritional quality: a review of practices in the Lake Victoria region. Fisheries and HI V/AIDS in Africa: Investing in Sustainable Solutions: WorldFish Center.

Kakati, B. K., Sharma P., \& Goswami, Ch. U. (2017). Quality evaluation of dried fish products commerce in Assam, India: International Journal of Advanced Biological Research, 7(3), 465-469.

Kilic, A. (2009). Low temperature and high velocity (LTHV) application in drying: Characteristics and effects on the fish quality. $J$ Food Engin, 91(1), 173-182. https://doi.org/10.1016/j.jfoodeng.2008.08.023

Kirk, R. S., \& Sawyer, R. (1991). Pearson's Composition and Analysis of Foods. Longman Scientific Publisher, London.

Legros, D., \& Luomba, J. (2011). Dagaa Value Chain Analysis and Proposal for Trade Development SF/2011/19: Implementation of a Regional Fisheries Strategy for the Eastern-Southern Africa and Indian Ocean Region

Malle, P., \& Poumeyrol, M. (1989). Journal Food Protection, 50, 419-423. https://doi.org/10.4315/0362-028X-52.6.419

Masette, M. (2013). Value-chain analysis of sun-dried mukene in Uganda. Food Chain, 3(1\&2). https://doi.org/10.3362/2046-1887.2013.006

Mbunda, A. E. (2013). The quality changes in smoked and dried fresh water sardine (Rastrineobola argentea) and marine pelagic fish (caplin) as influenced by processing methods.

Nguyen, V. M., Thorarinsdottir, K. A., Thorkelsson, G., Gudmundsdottir, A., \& Arason, S. (2012). Influences of potassium ferrocyanide on lipid oxidation of salted cod (Gadus morhua) during processing, storage and rehydration. Journal of Food Chemistry, 131(4), 1322-1331. https://doi.org/10.1016/j.foodchem.2011.09.126

Nielsen, S. (2010). Food Analysis (4th ed.). New York: Springer US. https://doi.org/10.1007/978-1-4419-1478-1

Odoli O. C. (2015). Drying and smoking of capelin (Mallotus villosus) and sardine (Sardinella gibbosa) - the influence on physicochemical properties and consumers acceptance: Dissertation for the Degree of Doctor of Philosophy

Onyuka, J. H. O., Kakai, R., \& Ofulla, A. V. O. (2014). Bacterial contamination dynamics and fungal contamination levels of fish Rastrineobola argentea and Oreochromis niloticus from Lake Victoria Basin of Kenya. Photon, 106, 179-188.

Sam, F. J., Jeyasanta, I. K., \& Patterson, E. J. K. (2015). Aflatoxins Investigation on Dried Fishes of Tuticorin, South East Coast of India. Journal of Foodborne and Zoonotic Diseases, $3(4), 49-62$

Saritha, K., Immaculate, K. J., Aiyamperumal, V., \& Patterson, J. (2012). Microbial and Biochemical Qualities of Salted and Sun-Dried Sea Foods of Cuddalore, Southeast Coast of India. Intl. J. Microbiol. Res., 3(2), 138-143. 


\section{Macrothink}

Ssebisubi, M. (2011). Analysis Of Small-Scale Fisheries' Value-Chains In Uganda.

Ssebisubi, M. (2013). The Status Fishing Communities in Buikwe District Uganda.

URN. (2012). Processed Mukene Fish Products Hit Supermarket Shelves. Uganda Radio Network.

\section{Copyright Disclaimer}

Copyright for this article is retained by the author(s), with first publication rights granted to the journal.

This is an open-access article distributed under the terms and conditions of the Creative Commons Attribution license (http://creativecommons.org/licenses/by/4.0/). 